\title{
Linguistic and Stylistic Means of Satire Construction in the Animated Series
}

\author{
Olga V. Demina \\ Peoples' Friendship University of Russia (RUDN University), \\ 6, Miklukho-Maklaya street, Moscow, Russian Federation, 117198 \\ $\checkmark$ deptphilology@gmail.com
}

\begin{abstract}
The study is devoted to the description of linguistic and stylistic means of satire construction in modern American animated series. The article deals with a detailed analysis of the linguistic and stylistic means that actualize the satiric and ironic meanings for a satire creation based on the examples of American series. Cartoonists often resort to satire as a unique genre of art to express direct or indirect criticism of the structure of modern society. Modern satirical cartoons contain vivid elements of parody and caricature. An obligatory consequence of satirical creativity is exposure and laughter. The methods of socio-political satire of modern animated serials are enhanced by the interplay of irony and sarcasm, hyperbole and grotesque, allegory and allusion, paraphrase and play on words. American animated series mirror modern reality, they reflect numerous facts of daily life and current environment touching their most critical sides: economics, politics, education, religion, ethnic issues, international ties and relations, interpersonal dealings. Socio-political satire is peculiar in that it does not spare not only the ruling branch of power, but also an ordinary, ordinary, gray person. In this dullness and ignorance of his, the average man in the street is ready to blindly obey the most ridiculous and absurd orders. Of course, an animated series cannot solve acute social or political problems facing society. But the fact that these questions are raised means that the problems are urgent. The purpose of such satire is to reflect on mistakes and not repeat them in the future. For example, "South Park", "Rick and Morty", "Family Guy", "F is for Family" parody the modern family, social order, exaggerate social issues to the extreme. The relevance of this study is due to several reasons: first, the abundance of cartoon products on the modern film industry market. Secondly, the role that cartoons and serials play in the life of a modern person and in the culture of postmodernity. It is common knowledge that over the past few years, the TV series and animated series industry has changed a lot: streaming services (Netflix, Hulu and Amazon) appear, new formats are released, and more and more cartoon characters are voiced by famous actors. Thirdly, it is confirmed by the idea of the existence of the phenomenon of the "Big Serial Bang", expressed by Doctor of Philosophy, Professor of the Higher School of Economics V.A. Kurenniy. The fact that modern TV series are a cultural product that accurately reflects the spirit of the times remains an indisputable fact. Such a visual narrative fits perfectly into the framework of modern society.
\end{abstract}

Keywords: socio-political satire, implicitness, explicitness, parody and caricature, irony and sarcasm, hyperbole and grotesque, allegory and allusion, paraphrase and play on words

(C) Demina O.V., 2021

This work is licensed under a Creative Commons Attribution 4.0 International License https://creativecommons.org/licenses/by/4.0/ 


\title{
Financing. Acknowledgement
}

The reported study was funded by RFBR according to the research project № 19-012-00014 «Reconstruction of the content of the conceptual fields of systemic linguistics»

\section{Article history:}

Received: 01.02.2021

Accepted: 15.09.2021

\section{For citation:}

Demina, O.V. (2021). Linguistic and Stylistic Means of Satire Construction in the Animated Series. RUDN Journal of Language Studies, Semiotics and Semantics, 12(4), 1124-1146. doi: 10.22363/ 2313-2299-2021-12-4-1124-1146

УДК 811.111:82-7:004.928

\section{Лингвистические и стилистические средства создания сатиры в современных анимационных сериалах}

\author{
Olga V. Demina \\ Российский университет дружбы народов, \\ 117198, Россия, Москва, ул. Миклухо-Маклая, 6 \\ $\checkmark$ هeptphilology@gmail.com
}

\begin{abstract}
Аннотация. Исследование посвящено описанию лингвистических и стилистических приемов создания сатиры в современных американских анимационных сериалах. В статье проведен подробный анализ лингвистических и литературных средств, актуализирующих сатирические и иронические смыслы для создания сатиры на примерах американских сериалов. Мультипликаторы часто прибегают к сатирическому жанру как уникальному виду искусства для выражения прямой или косвенной критики устройства современного общества. Современные анимационные сериалы часто содержат яркие элементы пародии и карикатуры. Обязательным следствием сатирического творчества становятся обличение и смех. Приемы сатиры современных сериалов усилены такими средствами художественного изображения, как ирония и сарказм, гипербола и гротеск, аллегория и аллюзия, перифраз и игра слов. Современные мультсериалы являются зеркалом современной действительности, они отражают реалии нашей ежедневной жизни, затрагивают ее важнейшие стороны: экономику, политику, образование, религию, этнические вопросы, международные связи и отношения, межличностные отношения. Феном сатиры своеобразен тем, что он не щадит не только правящую ветвь власти, но и обычного, заурядного, серого человека. В этой своей серости и невежестве среднестатистический обыватель готов слепо повиноваться самым нелепым и абсурдным приказам. Безусловно, мультипликационный сериал не может решить острых социальных или политических проблем, стоящих перед обществом. Но то, что эти вопросы подняты, означает, что проблемы актуальны. Цель такой сатиры - задуматься над ошибками и не повторять их впредь. Например, «Южный Парк», «Рик и Морти», «Гриффины», «С значит Семья» пародируют современную семью, высмеивают общественный строй, гиперболизируют социальные вопросы до крайности. Американские мультсериалы в этом смысле являются неиссякаемым кладезем интересных примеров сатиры и, в особенности, ее социально-политической составляющей. Актуальность данного исследования объясняется несколькими причинами: во-первых, изобилием мультипликационных продуктов на современном рынке киноиндустрии. Во-вторых, ролью, которую мультсериалы и сериалы играют в жизни современного
\end{abstract}


человека и в культуре постмодерна. Общеизвестно, что за последние несколько лет индустрия сериалов и мульсериалов сильно изменилась: появляются стриминговые сервисы (Netflix, Hulu и Amazon), выходят новые форматы, все чаще мультипликационных героев озвучивают знаменитые актеры. В-третьих, подтверждается мыслью о существовании феномена «Большого сериального взрыва», выраженной доктором философских наук, профессором Высшей школы экономики В.А. Куренным. То, что современные сериалы представляют собой культурный продукт, предельно точно отражающим дух времени, остается бесспорным фактом. Такой визуальный нарратив совершенно уникально вписывается в рамки современного общества, оказывает сильное влияние на мировоззрение, поведение, психологию отдельно взятого индивидуума.

Ключевые слова: социально-политическая сатира, имплицитность, эксплицитность, пародия и карикатура, ирония и сарказм, гипербола и гротеск, аллегория и аллюзия, перифраз и игра слов

\section{Финансирование. Благодарности}

Настоящее исследование финансировалось РФФИ в рамках исследовательского проекта № 19-012-00014 «Реконструкция содержания концептуальных полей системной лингвистики»

\section{История статьи:}

Дата поступления: 01.02.2021

Дата приема в печать: 15.09.2021

\section{Для цитирования:}

Demina O.V. Linguistic and Stylistic Means of Satire Construction in the Animated Series // Вестник Российского университета дружбы народов. Серия: Теория языка. Семиотика. Семантика. 2021. Т. 12. № 4. С. 1124-1146. doi: 10.22363/2313-2299-2021-12-4-1124-1146

\section{Introduction}

"Every joke is a tiny revolution" George Orwell

Modern American animated series constitute an interesting research field across academic disciplines as they are replete with satirical texts which bring up topical social and political, philosophical and psychological issues. Contemporary animated cartoons are intended to catch the spirit of the age and share specific knowledge on relevant issues. However, the analysis of the cartoons from linguistic and stylistic perspective remains under-researched. This paper aims at contributing to the knowledge of modern animated series research by analyzing the linguistic and stylistic elements used for satire construction as a means of modern society illustration with its current problems and through the lens of satire to draw public attention to the problematic issues.

There is no doubt that film industry has turned into a powerful communication channel that arouses wider public interest using linguistic and/or stylistic means as a tool of expressing thoughts and ideas from a certain perspective. This specific peculiarity of language has turned artistic cinema discourse into an effective research field. Language experts over the years have been studying how language 
is specifically used in various genres to carry out communicative tasks. Strictly speaking, making different approaches to language in its message-oriented communication will enable linguists to appreciate how language is used for fulfilling communicative purposes that include dissemination of information and knowledge, awareness of social, economic, political, cultural and other related events that constitute an individual life as an integral part of society. Modern American animated series take the form of actual social and cultural artifacts and serve for reflecting the present-day realities.

This paper provides insight into creation of satirical effect by using the linguistic and stylistic devices.

The objects of the study are American animated series: «South Park», «Rick and Morty», «Family Guy», «F is for Family».

The subject of this research is the linguistic and stylistic means of the satire creation in the American animated series and the peculiarities of revealing its social, political, philosophical and psychological elements within the framework of the original English-language texts.

The objective of this work is to reveal the mechanisms for creating satire and to determine the linguistic and stylistic means of its expression in the studied texts.

To reach this objective, it is possible to put the following tasks:

- to study animated series texts as a special kind of text;

- to examine the genre of satire, reveal its social and political, philosophical and psychological peculiarities;

- to analyze the linguistic and stylistic devices of the satire creation.

American animated series are very popular not only in the USA but abroad as well.

The relevance of this research is determined by the following reasons.

1) The abundance and oversupply of animated series products on the modern film industry market due to the development of the technical capabilities of cinema equipment, as well as the increasing introduction of modern technologies into the communication process, leads to a convergence of the visual image and the verbal side of communication and practically merging them into a single type of text that is of interest for study.

2) The role that American animated series play in the life of a modern person and in the culture of postmodernity. It is common knowledge that over the past few years, the TV series and animated series industry has changed a lot: streaming services (Netflix, Hulu and Amazon) appear, new formats are released, and more and more cartoon characters are voiced by famous actors. The popularity of films and blockbusters is being constantly replaced by the boom of modern series.

3) It is confirmed by the idea of the existence of the phenomenon of the «Big Serial Bang», expressed by Doctor of Philosophy, Professor of the Higher School of Economics V.A. Kurenniy. The fact that modern TV series are a cultural product that accurately reflects the spirit of the times remains an indisputable fact. Such a visual narrative fits perfectly into the framework of modern society [1]. 
4) When considering verbal means of creating humorous effect, much attention was paid to the analysis of the written text of a work of art. So, theoretical studies of the nature of the humor were reflected in the works of Yu.B. Borev and V.V. Vinogradov, whose works are devoted to the definition of the concepts «humorous means» and «humorous device» [2. P. 197-235; 3. P. 162]; S. Attardo, who discusses the textual organization of jokes and the relationship between the linguistic form and the content of the humorous text [4].

\section{The Genre of Satire}

In modern linguistic literature, the study of satirical and comic effects is paid little attention to. The analysis of satire and comedy still remains under-researched filed which deserves deep and detailed study [5. P. 92-95]. The system of linguistic means that serve for creating a comic effect remains open. This problem can be explained by the fact that a single unified system, which would include a set of all language comic effect tools, has not been developed yet [6. P. 82-116].

The means and techniques for creation of the satirical and comic effect attracted attention in ancient times [7. P. 45-48]. A special contribution in the field of satire and comedy was made by V.V. Vinogradov [3]. Considering simultaneously the means and techniques of satire and comedy, they both focused on the same elements such as: the principle of unexpected combination of words and expressions with different meanings, pointed metaphor based on an ironic comparison of images with animals and plants, a figurative comparison and confrontation, irony based on linking words with contradictory meanings, comic puns, synonyms of words with opposite meanings, skillful expertise of combination of author's speech with an image" [8. P. 4-8].

It is known that the factors which contribute into connection of the satirical and comic effects with the language of art literature are the means of its realization. In theoretical literature the terms of "means" and "methods" are hardly separated and are widely used in parallel with each other. For example, one of the researches is $\mathrm{Yu}$. Borev who resorts to using of both terms and does not make any strict differences [9. P. 8-12].

Another famous researcher of comic and satire, B. Dzemidock, in his work, devotes a special attention to the study of its forms and methods. He distinguishes five techniques for creation of a satirical and comic effect:1) modification and deformation of phenomenon; 2) unexpected effects; 3) disproportion in relations and between phenomena; 4) an imaginary unification of absolutely dissimilar phenomena; 5) the creation of phenomena that deviate from the logical or praxeological norm [10. P. 76-77]

The power of comic work of art, the significance of humour and satire depends on the author's choice of linguistic means, their appropriate use and skillful introduction in the text. This statement confirms integral unity of the comic means and methods. It is impossible to create a comic character and conflict without linguistic means of comic and satirical effect. The plot of a comic work of art is 
gradually filled with comic means which contribute to the general development of comic techniques [11. P. 17-19].

Comic language means cover all expressive means of the language, they are identical with the means used in lyric, epic and dramatic works [12. P. 99-102]. However, the main task of a comic master is the use of linguistic means in a comic way. A satyr master, the creator of humour, must be able to find a satirical or humorous coloring, to choose the right linguistic and stylistic means which can produce a satirical or comic effect, to use a satirical tone and a comic intonation in his or her work of art [13. P. 2-4]. Thus, comic means are determined by two essential factors: intonation and a comic or satirical quality, formed by the language itself [14].

The most complete realization of comic category belongs to satire, which, in order to expose vices and imperfections, creates a symbiosis of humour, irony, sarcasm and other comic forms. Consequently, satire is a prototype that has common properties with other units of the category $[15 ; 16$. P. 543].

\section{Satirical devices}

Satire is a genre of literature in which vices of people, abuses of government, follies of society are denounced and ridiculed. The formal definition of satire is «the use of humor, irony, exaggeration, or ridicule to expose and criticize people's stupidity or vices» [17. P. 143]. It is an extremely broad category. But satire has two important functions:

1. It derides people, ideas, institutions;

2. Its purpose is to inform and make people think critically.

In the twenty-first century it has been acknowledged that political and social satire experiences gain traction, as everyone seems to be on the joke [18], while the Internet has proved that there is no topic which is out of bounds:

Elli Foreman-Peck, an illustrator of the Economist, confirms: «People will always enjoy looking at people, and caricature is a way of displaying someone's psychological traits and demeanours in the physical realm, which is very satisfying. I believe it will morph into something different but at its core the desire to capture a person's essence through imagery will always be appealing and engaging» [19].

American animated series are cartoons designed for adults, but they are united by the common goal - a satirical portrayal of modern American political and social structure. Each episode makes people laugh at. However, this laughter is a laughter at themselves, because, in fact, such satirical cartoons are created to show in a satirical way American society and government, filmed in a form of comic description. «South Park», «Rick and Morty», «Family Guy», «F is for Family» have bright satirical features. The methods of satirical image are highlighted by using parody and caricature, irony and sarcasm, hyperbole and grotesque, allegory and allusion, paraphrase and play on words.

Modern animated series highlight the most incisive social issues: unemployment, organized group crimes, migration, poverty, dissatisfaction with the authorities. 
They bring up topical and relevant political issues: the class divide, corrupted authorities, the rights of ethnic minorities, racial conflicts, terrorism, riots and strikes, as well as it covers philosophical and psychological ones [19].

The main stylistic means of satire realization are:

Satire is «the use of humor, irony, exaggeration, or ridicule to expose and criticize people's stupidity or vices» [20].

Irony happens when come «two contradicting meanings of the same situation, event, image, sentence, phrase, or story. In many cases, this refers to the difference between expectations and reality» [20].

Sarcasm «a kind of verbal irony that has a biting or critical tone, although it can be used to express affection between friends It is one of the most common forms of irony in fiction and in real life» [20].

Hyperbole is a «figure of speech in which an author or speaker purposely and obviously exaggerates to an extreme. It is used for emphasis or as a way of making a description more creative and humorous. It is important to note that hyperbole is not meant to be taken literally; the audience knows it's an exaggeration» [20].

Let me provide a list of abbreviations which are used in the following part: $\mathrm{S}$ - season;

E - episode. Each example is specified by a number of the season and episode in which it occurs.

\section{Linguistic and Stylistic Analysis of Satire based on "South Park»}

South Park, a satirical show of high ratings, deals with religion and belief systems, encompasses the entirety of the traditional political spectrum, tackles all kinds of prejudice, the absurdity of daily life, it refers endlessly to popular culture and stereotypes. It covers all current international events and brings up topical issues.

The first example is taken from season 24 episode 1 which is called The Pandemic Special. It is dedicated to surge of COVID-19 pandemic, covers lockdown, social distancing, protective masks and gloves, and it focuses on distant learning. The episode starts with blaming people for not wearing masks properly during the outbreak of pandemic:

Stephen Stotch: Do you people mind? You're supposed to wear your mask over your nose. Looks like you're wearing a diaper for your chin. Chin diapers don't help [21. S24E1].

In the above-mentioned statements there is an example of sardonic sarcasm. The oral reprimand here demonstrates a verbal irony expressed in a biting tone. Sarcasm in that case is mostly sardonic because a character users a cynical comment to mock people who do not care about putting the masks properly so that they could cover their nose and mouth but not their chin.

Face masks are supposed to prevent respiratory droplets from reaching others, while a diaper is a piece of soft towel or material which you fasten round a baby's bottom in order to soak its urine. So, medical masks are compared with diapers on purpose to show not only their different function, but also a position. Thus, a 
figurative comparison is used in that example to characterize one object by comparing it with another object belonging to the opposite semantic class.

Another example refers to distant learning during pandemic. One of the main characters called Eric Cartman feels pleased to stay in during the lockdown, gets cheerful about the school that still remains closed because of the pandemic and enjoys the possibility of missing online school classes, inventing weak wifi connection and problems with Zoom classes. He adapted quickly to a new form of education. In this episode Erik is singing a song about e-learning and social distancing, expressing his deep satisfaction:

\section{Eric Cartman:}

Another day inside,

Don't have to do a thing

I love you, social distancing.

No one's around,

No one's talking to me.

Social distancing, I'm free.

Don't have to brush my teeth or shower.

For what?

I can sit on the toilet for hours

As long as I want

Cause no one's saying to me

You kids should get outside and do something. [21, S24E1]

The expression of social distancing, also called physical distancing, is a set of pharmaceutical measures intended to prevent the spread of infection. It has become especially widespread during the coronavirus pandemic. According to Eric's perception, it means doing nothing, being free, not having to do toilet, staying inside. That is an example of hyperbole - a figure of speech in which the speaker obviously exaggerates the meaning of social distancing. Eric Cartman overestimates its meaning and misinterprets the phenomenon.

School shooting is another topical issue nowadays. According to statistics data published by Statistics Research Department this October, in 2020 there were 79 school shootings in the USA. The alarming rate of school shootings is highlighted in season 22 episode 1 called "Dead Kids".

Mother: Stanley... Well? Do you want to tell your father about what happened at school today?

Sharon Stanley: Um..O-oh. I flunked my math quiz.

Mother: No! The other thing!

Father: What other thing? What happened at school today?

Sharon Stanley: Oh, the school shooting?

Mother: Yes! The school shooting!

Sharon Stanley: Oh, yeah. Some kid shot up the school.

Father: Who shot up the school? Was it you?

Sharon Stanley: No.

Father: Did you get shot? 
Sharon Stanley: No.

Father: Oh. Well. What's this about failing a math quiz?

Mother: Are you serious? Did you not hear what your child said?! Kids died at his school!

Father: I'm sorry, Sharon. I...

Mother: Why are you all acting like this is normal? [21. S22E1]

The subject of satire here is a school shooting. The key issue of the episode is to bring community's attention to juvenile criminal prosecution. The main linguistic technique of conveying the message is cynical sarcasm. The cynical element is the habit of having skirmishes at school. Firstly, Sharon forgets to mention the event to his father, he believes that his mark on the test is more relevant at the given moment. Secondly, father doesn't show any surprise of hearing the news. He only wants to know who is the shooter and if his son is not hurt. The didactic purpose of this satire is to demonstrate the high level of armed assaults and aggression happening on a regular basis in American schools nowadays as well as to witness a dreadful transformation of such crimes into insignificant daily events.

It should be noted that parody and caricature have become an integral part of political and social genre in American animated series. There are thirteen celebrities who are brightly exposed in South Park. They are Kanye West, Barbara Streisand, Mel Gibson, Tom Cruise, James Cameron, Michelle Obama, Ben Affleck, Jennifer Lopez, Paris Hilton, Donald Trump, Michael Jackson, Phil Collins, Isaac Hayes.

According to the linguistic and stylistic analysis of satire creation in «South Park», it should be noted that the most frequent devices for satire creation are irony and sarcasm - 43\%, the least often — parody and caricature. The percentage distribution of all linguistic and stylistic devices is shown on the Fig.1.

\section{South Park}

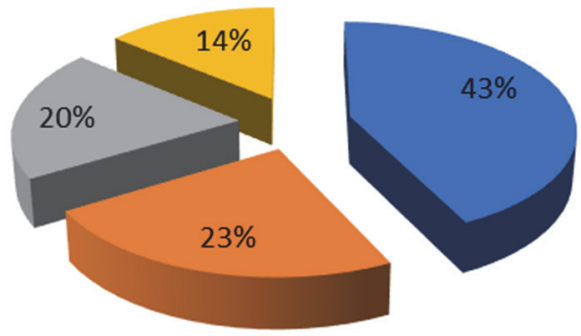

$$
\begin{aligned}
& \text { irony and sarcasm } \\
& \text { nyperbole and grotesque } \\
& \square \text { allegory and allusion } \\
& \text { parody and caricature }
\end{aligned}
$$

Fig. 1. Percentage-based rations of linguistic and stylistic devices distribution

Рис. 1. Процентное соотношение лингвистических и стилистических приемов сатиры

\section{Linguistic and Stylistic Analysis of Satire based on «Rick and Morty"}

"Rick and Morty" is another American animated comedian sitcom which tells us about interdimensional adventures of an eccentric scientist Rick Sanchez and his 
14-year-old grandson Morty Smith. The series are considered to reveal the insignificance of human existence compared to the size of the universe, to tackle with its absurd and chaotic nature. "Rick and Morty" was acclaimed internationally as the top-rated series with $94 \%$ according to review aggregator website Rotten Tomatoes. [https://www.rottentomatoes.com/tv/rick-and-morty]

"Rick and Morty" is replete with references to existential and absurdist philosophy.

a) Morty: Rick, what about the reality we left behind?

Rick: What about the reality where hitler cured cancer, Morty? [22. S1E6].

b) Morty: Nobody exists on purpose, nobody belongs anywhere, everybody's gonna die. Come watch TV [22. S1E8].

The above utterances a) and b) target philosophy of science and philosophy of religion as an object of satire. In a), Morty assumes philosophical questions about the nature of reality (What about the reality we left behind) which can be opposed to imaginary world, while in b), Morty considers ontological questions of existence (Nobody exists on purpose, nobody belongs anywhere, everybody's gonna die), which is a major branch of metaphysics. The satirical effect is achieved by using alogism, a literary device which presumes on the destruction of logical links. Thus, deep philosophical judgements in both above-mentioned examples are followed by illogical statements like a) What about the reality where Hitler cured cancer? and b) Come watch TV. To conclude, it should be noted that existential and absurdist philosophy can be considered there as a subject of satire as it identifies the values which are deeply ingrained in humanity. The type of satire is definitely philosophical.

Within the framework of philosophical idea of existentialism, "Rick and Morty" satirizes and depreciate traditional social structures such as the institutions of marriage, family, religion, and government.

The further example considers art of living in the philosophical discourse. Such concepts as success, pleasure, love and happiness are in the spotlight.

Rick: Listen, Morty, I hate to break it to you, but what people call "love" is a chemical reaction that compels animals to breed. It hits hard, Morty, then it slowly fades, leaving you stranded in a failing marriage. I did it, your parents are gonna do it. Break the cycle, Morty. Rise above. Focus on science. (exits room, drinking juice) [22. S1E6].

From such a practical perspective, the categories of love and marriage are not validated any more in modern society ("love" is a chemical reaction that... slowly fades, leaving you stranded in a failing marriage.), cultivation of the soul comes to the fore (Break the cycle, Morty. Rise above. Focus on science.). Cynicism, as a literary device, is intended to skewer moral values and social conventions. Unlike sarcasm, cynicism pinpoints generally negative or pessimistic outlook on human life. People's behavior is defined by self-interest.

Another topic concerns the clash of opinions on the gender role in a contemporary society. 
Rick: Summer, put your burqa on!

Summer: That burqa is a human rights violation, and I spent a lot on this top.

Rick: The least you could do is be ashamed of your gender.

Summer: What's the deal with this place? Why is it such a sausage planet and how did such backwards idiots invent robots?

Rick: Obviously at some point the Gazorpians became so evolved that they replaced females with birthing machines [22. S1E7].

The object of satire in the above-given paragraph is muslim identity in modern society. The subject of satire is wearing burqa in public places. According to Cambridge Dictionary burka (also burqa) or niqab is "a piece of clothing that covers the whole head and body, with a hole for the eyes, worn by some Muslim women". Wearing burqa causes heated political discussions, provokes anxiety and protests from Western cultures. Such oppression of Muslim women's clothing is explained by the sign of religious extremism and possible political militancy instead of a religious duty or an Islamic prescription. The dialogue is supposed to bring attention to Islamic extremism and Europian/American Islamophobia. For Summer, a young American girl, being forced to wear burqua is considered to violate human rights. Rick is trying to persuade her to put it on and pretend to be ashamed of being a woman. It refers to Islamic women who are believed to be agreeable and obedient wives.

The planet Gazorpazorp is inhabited only by women who rule it. Summer called it a sausage planet and its residents backwards idiots. A qualitative hyperbole is used as a literary technique, as the speaker takes up the most extreme negative evaluation possible when describing the planet and its people. The satire can be classified as social one as it turns out to catch common behaviors in modern society which are rather negative. The classification of that type of satire is both political and social.

\section{Summer: Grandpa!}

Gazorpian: Grandpa? That sounds patriarchal. It means "father offathers". Then this one is not your slave and your earth is yet another planet dominated by men.

Rick: It's not dominated by us, okay? On earth men and women are equals.

Summer: Equals? We make 70\% of your salary for the same job [22. S1E7].

The object of satire is feminism. The subject is social and political gender equality. The quantitative hyperbole ( $70 \%$ of your salary) is used to demonstrate the unequal distribution of finance resources for the same duties at workplace performed by men and women. The rhetorical question (Equals?) is asked to emphasize the point that the role of men and women in business on Earth is not equal. The answer is immediately provided by the speaker in a form of morphosyntactic exclamation.

In "Look Who's Purging Now" Rick and Morty land on a planet in the same day when their residents are celebrating a festival called "Purge". During that night people are allowed to commit crimes of any kind and will not be punished.

The Pedestrian: Ooh, well, for millennia our society has been free of crime and war, living in perfect peace. 
Rick: I know what this is! You can sustain world peace because you have one night a year where you all run around robbing and murdering each other without consequence.

That's right!

Morty: What?

It's like The Purge, Morty. That movie The Purge [22. S2E9].

The satirical effect in the above-mentioned dialogue is based on grotesque, as it signifies a state of affairs in which "the natural order of things has been subverted".

The plot of the episode is a parody on "Animal Farm" written by G.Orwell, a sarcastic portrayal of exploitive political system. The planet is run by the upper class who exploit the lower class citizens and people from the lower class have to build a new system from scratch.

Arthrisha: I....I never intended to harm you, I swear. I am trying to end the festival.

Rick: W-what do you mean?

The Girl: I was going to use your ship to destroy the rich ...that run our society, and save people from the horrors of this yearly festival...

Rick: Now where are these rich people?

Rich people: To another successful year of the festival! Pitting poor people against each other for thousands of years!

The following examples demonstrate the creation of new words for producing comic effects. They are:

a) Morty: Wow. What do you know? Huh. That was easy.

Rick: Totes malotes, dawg.

Morty: Just kind of hard to believe, you know? [22. S1E4].

b) Brad: I throw balls far. You want good words, date a language [22. S1E6].

c) Slippery: Y'all need to ride down the stairs? My name is slippely-slippery stair. I'll take you down there for 25 shmeckels.

Rick: 25 shmeckels? I don't know how much I don't know what that is. Is that a lot? Is it a little?

Waitress: That's exactly how much I spent on my big fake boobies [22, S1E5].

The comic effect is based on wordplay which is supposed to represent the concept of neologism. There are three examples of neologisms in the conversation: a) 'totes malotes', b) 'a languager' and c) 'shmeckles'.

According to Urban Dictionary, the phrase of 'totes malotes' is a combination of totes, which presumes a different way of saying 'totally', and 'malote' which is a Mexican-American slang for a rude word or an insulting. The expression (Totes malotes, dawg.) became fixed, got a popular meaning ('well done!' or 'too easy') and possibly originated from "Rick and Morty" [23].

The expression b) 'date a languager' seems to be correct, the derivational suffix $-e r$ is added to the noun language to signify a person who is an expert in a language, a linguist. Nevertheless, the wordplay lies in the fact that the lexeme 'a languager' does not exist in the English language and it is used to pre-empt the 
existence of a noun denoting the same meaning - a linguist. The ungrammatical creation of the noun ' a languager' is highly unpredictable, though it can be possibly taken for a neologism.

The noun 'shmeckles' does not exist in any English dictionary, except for Urban Dictionary where it is defined as a male part of the body of little size. [https://www.urbandictionary.com/define.php?term=shmeckle]. However, in the context the word 'shmeckles' is used as a currency in a pejorative way. Firstly, nobody is aware of its nominal value. Secondly, the required sum is always fixed and it totals 25 ('shmeckels'): 'to ride down the stairs' and 'big fake boobies' are on the same price list.

Rick: Sometimes science is more art than science, Morty [22. S1E6].

In this episode Rick has made a mistake by confusing the chemicals and turned people into monsters. Having seen the consequences of such a failure, he is trying to justify his error by comparing science and art.

Poncho: That's right, baby! A lot of people would pay top dollar to decimate the population. I'll take the highest bidder: Al-Quaeda, North Korea, Republicans, Shriners, balding men that work out, people on the Internet that are turned on by cartoons of Japanese teenagers, anything is better than working for you, you pompous, negligent, iTunes-gift card a holiday bonus giving mother [22. S1E3].

The following list of words includes some ergonyms: the name of organization (Al-Quaeda), the name of children hospital (Shriners), the name of the political party (Republicans), a toponym (North Korea), and free collocations (balding men; Japanese teenagers). This is an example of zeugma being used for making a humorous effect. The basic function of zeugma is to puzzle and astonish. Al-Quaeda should be followed by another name of a terrorist organization, but the use of North Korea violates the expectation and puzzles the listener who is struggling to build a logic path. Then, comes the name of the political party and it results in the humorous image.

\section{Rick and Morty}

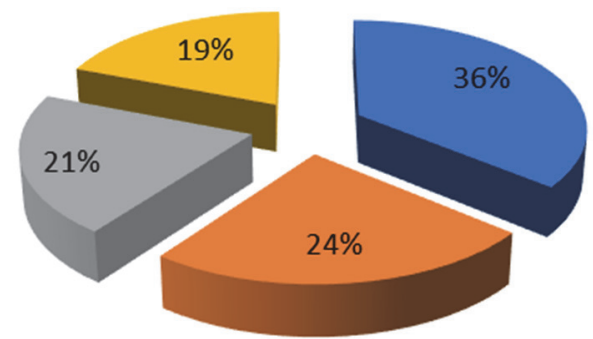

$$
\begin{aligned}
& \square \text { irony and sarcasm } \\
& \square \text { hyperbole and grotesque } \\
& \text { allegory and allusion } \\
& \text { parody and caricature }
\end{aligned}
$$

Fig. 2. Percentage-based rations of linguistic and stylistic devices distribution

Рис. 2. Процентное соотношение лингвистических и стилистических приемов сатиры 


\section{Linguistic and Stylistic Analysis of Satire based on "Family Guy"}

"Family Guy" is often compared with "the Simpsons" but still it has some peculiar features and qualities of its own: unlike "the Simpsons", "Family Guy" can be regarded as a source of sociological study in the context of American culture. "Family Guy" is considered to be one of the best series which can help to understand American society and its unique culture, as well as to discover interpersonal relationships and to enjoy the American sense of humour. It outlines family relationships in a colorful and humorous way, offers a fresh view on representations of adolescence, masculinity, femininity. Also, it deals with sensitive topics like homophobia, manifestation of racism, HIV/AIDs, sexism, stereotyping and violence.

The following example is taken from season 1 episode "I never met the Dead $M a n$ " and it takes a look at a pun that makes a play on the words 'bribe' and 'love' which sound different but have similar meaning 'pamper' or 'spoil'.

Lois Griffin: Peter, you're bribing your daughter with a car?

Peter Griffin: Come on, Lois, isn't 'bribe' just another word for 'love'? [24. S1E1].

The utterance 'you're bribing your daughter with a car' is based on the wordplay and it is supposed that Peter offers a car to his daughter as a gift to pamper her and make her do something in return. This argument can be supported by the lexical entry. In Longman dictionary the verb 'to bride' has two meanings: 1) to illegally give someone, especially a public official, money or a gift in order to persuade them to do something for you; 2) to offer someone, especially a child, something special in order to persuade them to do something. In both definitions it is stressed that a gift is given to somebody in order to encourage the person to do a favour or a service instead [25].

The next example is taken from episode called "Peter $I V$ " and it focuses on hyperbole or exaggeration which is one of the primary goals of humour.

Peter: Those Ruski bastards changed the movie so Drago wins!

Cleveland: Not only does he not get up, he's holding a sign that says, "Workers of the world, unite!"

Peter: Well, that-that seems like a logical idea, but this aggression will not stand! I am writing Vladimir Putin an angry e-mail. "Dear Vladimir..."

Cleveland: Ho-ho! That's telling him.

Peter: I hope this email will finds you well.

Cleveland: Oh, man, I wish I could see his face.

Peter: I'll get right to the point. "My friends and I were aghast when we saw what you did to the end of Rocky IV. Everyone knows that any American can beat up any Russian on any day of the week. Other than that, all is well on this end. Chris continues to hit the books as best he can, and his grades have shown some improvement. Stewie is growing like a weed. And Meg has become a woman in front of our very eyes". And... send.

Cleveland: I think we lost a little steam at the end [24. S16E7]. 
The main character Peter is going to call the Russian President and reprimand him for having changed the rules of boxing where the American boxer should have beaten the Russian opponent. The dialogue in this episode outlines two controversial points: 1) the fact that an unknown American citizen called Peter is able to send an email to any President at all, especially, to show any sign of anger ('this aggression will not stand! I am writing Vladimir Putin an angry e-mail') and 2) the idea of omnipotent Russian President who can interfere in internal affairs of any country and make necessary changes ('My friends and I were aghast when we saw what you did to the end of Rocky IV. Everyone knows that any American can beat up any Russian on any day of the week'). A hyperbolic statement is intensified by the grammatical construction 'I wish I could see his face'. The verb wish is used to speak about things and events that are not considered possible. The verb wish is followed by past tense modal could which denotes wishes made for the future.

Peter met a new friend called Stryker Fox and decided to put an end to the friendship with his old friends.

Peter: Ugh, it's the guys. What do those losers want?

Lois: Losers? Those are your friends.

Peter: Nah, they are lame. Not one of them has ever vaped at a funeral [24. S16E2].

Peter thinks that his friends are losers and calls them lame because they have never vaped at a funeral. This is an example of situational irony, which refers to the events that prove to be the opposite of what is expected. Finally, it turns out that his new friend dies and Peter tries to bring back his old friends which means that he did not really mean that his friends were losers.

\title{
Family Guy
}

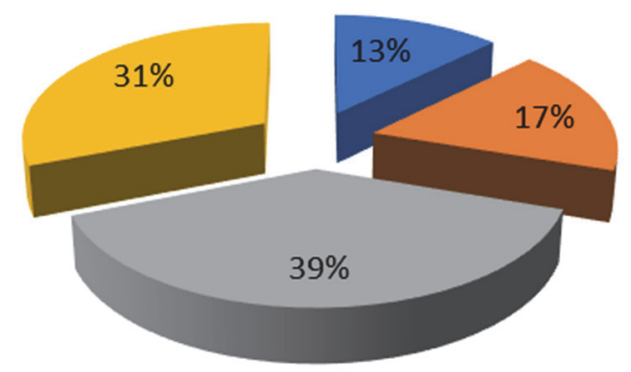

\author{
- irony and sarcasm \\ - hyperbole and grotesque \\ allegory and allusion \\ - parody and caricature
}

Fig. 3. Percentage-based rations of linguistic and stylistic devices distribution

Рис. 3. Процентное соотношение лингвистических и стилистических приемов сатиры

\section{Linguistic and Stylistic Analysis of Satire based on "F is for Family"}

"F is for Family" is an American adult animated series that tells about the Murphys, a middle class Irish-American family. " $\mathrm{F}$ is for Family" covers interpersonal 
relationships with friends, colleagues, family members and romantic partners. It also tackles such topics as a generation gap and existing confrontation between the generations, common marriage problems, moral values, work ethic and attitude toward different races and groups.

The following example aims at children's academic performance at school, a family daily routine and parents' hardships. The dialogue is conducted between a father (Frank) and a son (Kevin).

Frank: You got one job: pay attention and pass your classes.

Kevin: That's two jobs!

Frank: No son of mine is gonna flunk out.

Kevin: I don't care. I hate school!

Frank: Well, I hate my life, but I keep on doing it! I got a mortgage, I got dependents, and I gotta go downtown every damn day to run that airport!

Kevin: Please, you're just a baggage handler [26. S1E2].

It becomes apparent that Kevin, as almost any teenager, does not like going to school and studying. He has recently failed his test in history and his father has just learnt about it. There are some humorous elements: 1) two jobs (That's two jobs!), 2) expression of intense hatred (I hate school! — I hate my life) and 3) work duties (to run that airport and be just a baggage handler).

The first comic remark is based on the use of hyperbole which is intensified by the use of exclamation mark. Frank wants his son Kevin to fulfill just two simple tasks: be attentive at school and attend all the classes while Kevin perceives them as tasks of high importance, exaggerating each of them and equals them to a true job.

The second sarcastic utterance is built on the phrasal repetition (I hate) and a substantive opposition (I hate school! - I hate my life). There are two kinds of hatred: the one created by school and by life itself.

The last one is developed from the combination of hyperbole and understatement. Franks exaggerates his professional occupation at the airport when he confirms that he runs the airport while his son, Kevin, downgrades his father's social status by saying he is just a baggage handler.

As Kevin keeps on missing his classes, his father decides to play a joke on him by saying that he is bringing him to the Army.

Frank: Hey. Get up, son.

Kevin: Oh, come on, I was having a dream about not being part of this family.

Frank: That's great. Come on. It's important.

Kevin: Where you taking me? Look, I'm sorry, I'm flunking out, but History's not my fault. I wasn't gonna say this, but Mr. Hackett is always brushing up against me.

Frank: Look, I realize no matter how much I yell and scream, you're never gonna change. You're not gonna do better in school, and your mother and I have accepted that. We're not gonna fight you on this anymore. So, I guess you're done with school.

Kevin: Oh, cool.

Frank: So, we decided to sell you to the Army. You are going to Vietnam. It's called «Troubled Youths to Southeast Asia» or something like that. It's an earlyinduction program [26. S1E2]. 
In the above-mentioned example a delinquent teenager becomes an object of derision. His father threatens him with the army, inventing the name of an innovative program — «Troubled Youths to Southeast Asia» which is designed for the army recruits who are under the age of 18 years old. Frank's sarcastic remarks are intensified by the following sarcastic sentences: we're not gonna fight you on this anymore; you're done with school, you are going to Vietnam. Frank resorts to Kevin's emotions to realize his sarcastic intent by sounding accepted decision and by using future grammar forms: Present Continuous in the following sentences we're not gonna; you are going is used for expressing fixed arrangements in the near future.

Women's friendship is another curious topic which includes emotional intimacy and seems to be rather complicated. Ginny is Sue's friend who has just divorced and is always complaining about her failed marital status. The next example will demonstrate the complexity of female friendship.

Sue: Ginny, stop! The mall is closing. I've got to find Maureen and go home and make dinner.

Ginny: Oh, well, excuse me. I am so sorry that my life falling apart has inconvenienced you. Why'd I even bother talking to you at all? You can't understand how I feel with your perfect life and your beautiful kids.

Sue: My life isn't perfect, okay? Outside of being a wife and a mother I've got nothing. Sometimes I wish I'd never got married!

Ginny: Do you ever stop thinking of yourself? [26. S1E3].

The satirical effect is produced by using the repetitive apologies expressed by a synonymous range of phrases which are supposed to exaggerate true emotions of regret: 1) Oh, well, excuse me. 2) I am so sorry. 3) Why'd I even bother talking to you at all? The hyperbolic effect is achieved by using such word combinations as your perfect life and your beautiful kids. It is generally believed that your friends or colleagues or neighbours are luckier and happier in life that you are. Despite the fact that Sue is trying to explain that her life is not better than Ginny's, confirming that she wishes she had never been married, Ginny still feels upset and behaves herself in a very selfish way. She would like to be heard, however she is not ready to listen to other people's problems. She does not seem to understand Sue, finishing the dialogue in an egoistic way: Do you ever stop thinking of yourself?

Sue's daughter Maureen feels confused to have heard that her mother wishes to be single. Maureen interprets her mother's statement literally: Like your wish that you never got married?

Maureen: It was my wish.

Sue: Well, not all wishes come true.

Maureen: Like your wish that you never got married?

Sue: No. I didn't...No. That's not...I said that, but I didn't really mean it. I was, you know, just trying to make Ginny feel better.

Maureen: Oh. So when I heard Daddy say he wished he never got married, who was he trying to make feel better?

Sue: I will be sure to ask him that [26. S1E3].

Antiphrasis is used here to sharpen the contrast between a thought and a word. Sue pronounced that sentence to calm down her friend, she acknowledges that in 
fact she has not meant it (No. I didn't...No. That's not...I said that, but I didn't really mean it. I was, you know, just trying to make Ginny feel better.). Then, Maureen wanted to know who her father wished to settle down when he used the same statement: Oh. So when I heard Daddy say he wished he never got married, who was he trying to make feel better? People often pronounce words and phrases without meaning them in order to provoke the opposition reaction. Antithesis is a great way to add such a contrast.

The further dialogue focuses on the topic of unemployment. Frank has just lost his job and feels distressed:

Frank: "I can't take it anymore Sue, I'm sick of all these [f*.....] people looking at me thinking 'oh, you poor unemployed man'."

Sue: "Frank, no one is thinking that."

Jenny: "Hey there Sue, Frank, you poor unemployed man, how's the job search going?"

Frank: "I should have died in Korea" [26. S2E1].

In the above example the humorous effect is achieved through the simultaneous use of anaphoric repetition and parallelism "you poor unemployed man" which integrates the comic effect with the effect of enhanced emotionality and evaluation. The episode exposes fear of being unemployed, fear of the unknown, fear of losing control

"F is for Family" focuses on keeping friendly, open and respectful communication. It teaches people to overcome drastic differences, to build strong bonds with coworkers and friends, and to bridge the generation gap.

\section{$F$ is for Family}

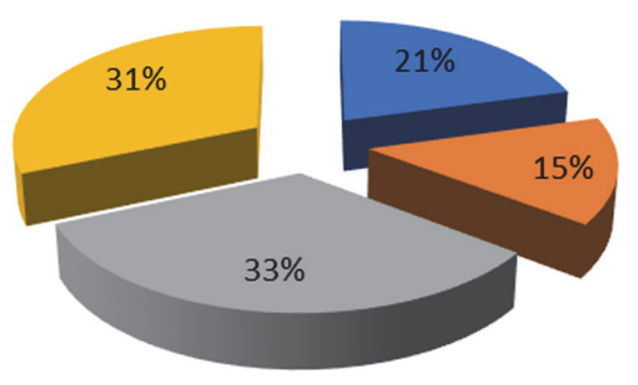

घ irony and sarcasm

- hyperbole and grotesque

a allegory and allusion

parody and caricature

Fig. 4. Percentage-based rations of linguistic and stylistic devices distribution

Рис. 4. Процентное соотношение лингвистических и стилистических приемов сатиры

\section{Results and Discussion}

According to the complex analysis of satire phenomenon in American animated series and their text scripts, I can conclude that the most frequent topics with social or political elements of satire are: 

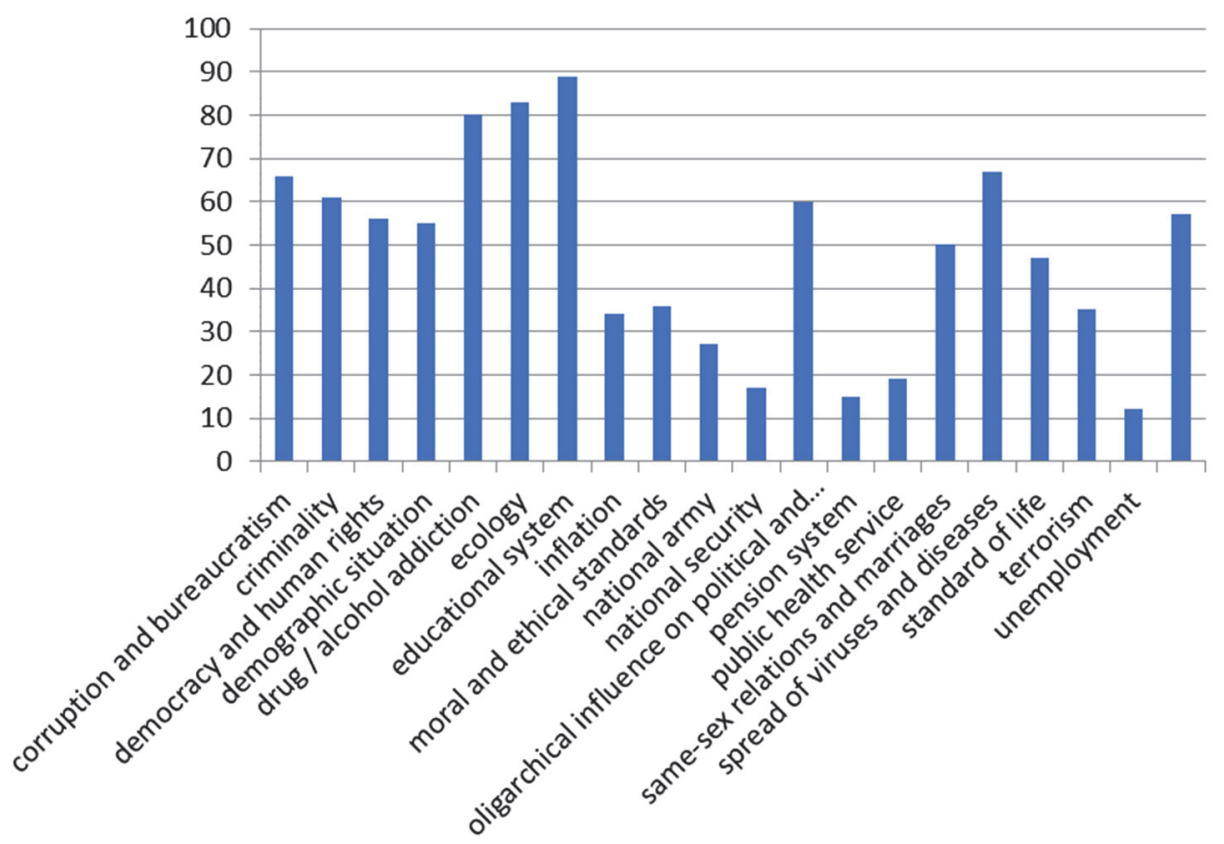

Fig. 5. Percentage-based rations of socio-political topics reference, which are criticized and satirized

Рис. 5. Процентное соотношение упоминание социально-политических тем, подвергающихся осуждению и высмеиванию

On Fig. 1 each segment displays the percentage ratio of socio-political references found in the process of my research. The derivation defines the relevance of revealed topics, stresses their significance in people's life, explains the potential of language to serve in a satirical way of animated messages.

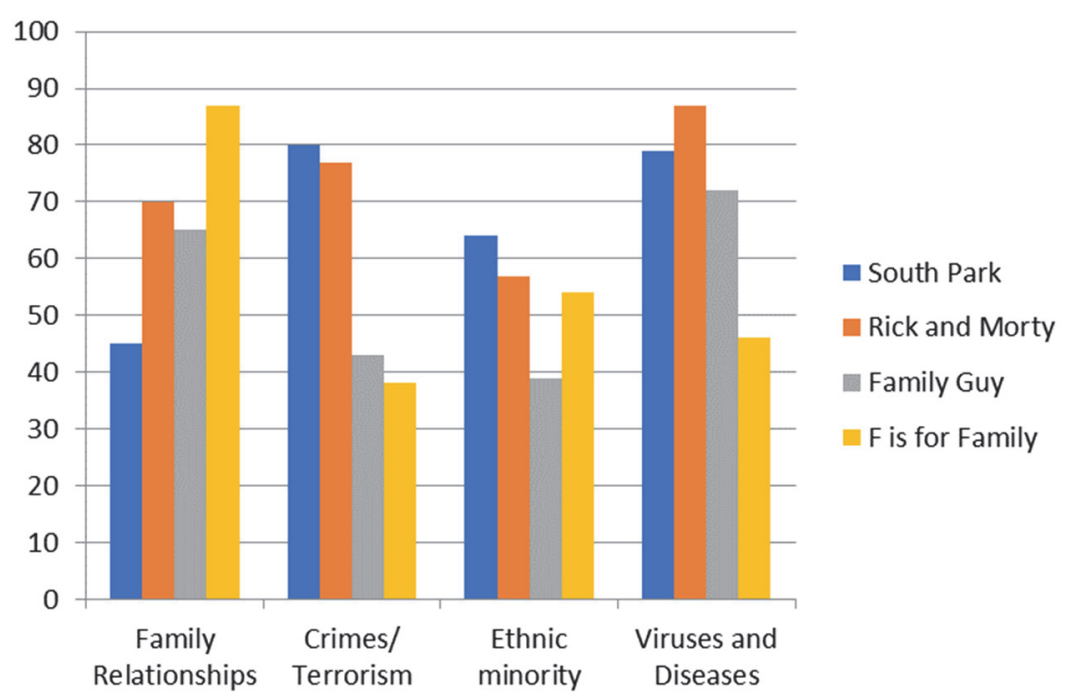

Fig. 6. Quantitative ratios of social-political topics distributed by series

Рис. 6. Количественные соотношения социально-политических тем, распределенные по сериалам 
On Fig.2 the bar chart illustrates the percentage of topics which have social and/or political elements in the above-mentioned series. A prominent feature is that a significantly low percentage of crimes / terrorism allusions presented in " $F$ is for Family" and family relationships in "South Park". The percentage of crimes / terrorism allusions is slightly higher in "Family Guy" than in "F is for Family".

\section{Conclusion}

In this paper I have argued for the use of linguistic and stylistic devices for construction of satire in modern animated cartoons. The aim was to contribute to debates in satirical genre regarding the importance of figures of speech such as irony and sarcasm, hyperbole and grotesque, allegory and allusion, paraphrase and play on words, parody and caricature to create a special ironical and/ or sarcastic effect as well as to show how the authors of the animated American series resort to vulgar, ambivalent humour to satirize mediocre people, entrenched habits, ruling ideologies and mindsets within the contemporary American society. Social and political, philosophical and psychological satire in modern animated cartoons serves as a powerful weapon for communicating social and political issues, philosophical and psychological problems, because such messages can easily be absorbed by young generation and transmitted in mass circulation. The genre of satire is of high social importance because it is used in setting social agenda and provides satirical commentary aimed at transforming social and political norms of society. The cartoonists exploit a wide range of linguistic and stylistic skills such as irony and sarcasm, hyperbole and grotesque, allegory and allusion, paraphrase and play on words. The satire brings about constructive criticism by using a sense of humour.

By analysing "South Park", "Rick and Morty", "Family Guy", "F is for Family", I have demonstrated the continued importance of such series in modern society worldwide not only for their satirical role, but instead for their social and political significance. All of them rely on a broad stock of cultural knowledge from which the sitcom creators intermix religious and philosophical ideas, moral principles, popular and high culture references.

Satire is a broad genre that incorporates a number of various approaches. It can be serious, acting as a protest, or comical, aimed at poking fun at something or someone. It can be explicitly or implicitly expressed. According to the topics that satire is intended to highlight, it can be classified into political, social, psychological or philosophical one. A combination of stylistic (irony, sarcasm, hyperbole or understatement, alogism, double-entendre) and linguistic devices (composition, syntactic ambiguity) can contribute into creation of successful satire which is supposed to produce a desired ironic effect.

\section{References}

1. Video lecture on the topic: Big serial explosion URL: https://www.hse.ru/news/ communication/119812549.html (accessed: 30.12.2020). 
2. Borev, Yu.B. (1970). The comic, or how laughter punishes the imperfection of the world, purifies and renews a person and affirms the joy of being. Moscow: Iskusstvo. (In Russ.).

3. Vinogradov, V.V. (1971). On the theory of artistic speech. Moscow: Vysshaja shkola. (In Russ.).

4. Attardo, S. (2002). Translation and Humour. The Translator, 8(2), 173-194. DOI: 10.1080/ 13556509.2002.1079913.

5. Cikusheva, I.V. (2008). Linguistic means of creating comic effect in fairy tales. Vestnik Adygejskogo gosudarstvennogo universiteta. Serija 2: Filologija i iskusstvovedenie, 10, 100-103. (In Russ.).

6. Luk, A.N. (1968). About a sense of humor and wit. Moscow: Iskusstvo. (In Russ.).

7. Kyazimov, G. (2004). The theory of the comic (problems of linguistic means and techniques). Baku: Taxsil, 2004. (In Russ.).

8. Bryuxanova, E.A. (2007). The cognitive-historical nature of irony: the paradigm of models in a comparative description: based on the material of English literary works of the 20th century and their Russian translations [dissertation]. Ekaterinburg. (In Russ.).

9. Baxtin, M.M. (1997). Satire. In: Collected works: in 7 volumes. Vol. 5. Moscow: Russkie slovari. pp. 11-38. (In Russ.).

10. Gorbacheva, I.M. \& Grishanova, Ye.V. (2018). Laughing Communication Role in Socio-Cultural Development of Society during Crisis Periods. Economic and Social Research, 2(18). URL: http://esgi-miet.ru/images/Stati20182/esgi2-18-2018.pdf (accessed: 02.11.2019). (In Russ.).

11. Grubova, A. M. (2017). Stylistic methods of creating a humorous effect (based on the novel by Helen Fielding “Diary of Bridget Jones”). Molodoj ucheny'j, 11(145), 319-322. (In Russ.).

12. Matasov, R.A. (2008). History of film translation. The Moscow University Herald, Series 22, Translation Theory, 3, 3-27. (In Russ.).

13. Matasov, R.A. (2010). Translation of film / video materials: linguocultural and didactic aspects [dissertation]. Moscow: Moskovskij gosudarstvenny`j universitet imeni M.V. Lomonosova. (In Russ.).

14. Sazonov, A. (2010). Double two (rus.). Formula Kino Gorodovoy, 8, 51-53. (In Russ.).

15. Snetkova, M.S. (2008). On the problem of translating feature films (based on two Russian translations of P. Almodovar's film "Women on the Verge of a Nervous Breakdown"). Moscow State University Bulletin. Series 9. Philology, 1, 56-62. (In Russ.).

16. Tatarincev, N.S. (2019). Film genres. Molodoj ucheny'j, 21(259), 541—547. (In Russ.).

17. Fedorova, I.K. (2009). Translation of film text in the light of the concept of cultural transfer: the problem of translation adaptation. Vestnik Cheljabinskogo gosudarstvennogo universiteta. Serija: Filologija. Iskusstvovedenie, 43, 142-149. (In Russ.).

18. Geopolitics. Volume 21, 2016 - Issue 1: article: Joe Thorogood Satire and Geopolitics: Vulgarity, Ambiguity and the Body Grotesque University College London UK pp. 215-235; 2016 [site]. URL: https://www.tandfonline.com/doi/full/10.1080/14650045.2015.1089433 (accessed: 02.01.2021).

19. Caricature and political cartoons: essential satire or old news [site]. URL: https://www.itsnicethat.com/features/spitting-image-the-future-of-caricature-sculpture-illustration071020 (accessed: 02.01.2021).

20. Slovar' literaturny'x terminov: [site]. URL: https://iteraryterms.net/satire (accessed: 02.01.2021).

21. South Park: [site]. URL: https://www.southparkstudios.com (accessed: 10.12.2020).

22. Rick and Morty: [site]. URL: https://www.adultswim.com/videos/rick-and-morty (accessed: 17.12.2020).

23. Urban Dictionary: [site]. URL: https://www.urbandictionary.com/define.php?term=Totes\% 20Malotes (accessed: 17.01.2021).

24. Family Guy: [site]. URL: https://www.fox.com/family-guy (accessed: 25.12.2020).

25. Longman Dictionary: [site]. URL: https://www.ldoceonline.com/dictionary/bribe (accessed: 02.01.2021)

26. F for Family: [site]. URL: https://www.netflix.com/f-for-family/ (accessed: 28.12.2020) 


\section{Библиографический список}

1. Видео-лекция на тему: Большой сериальный взрыв. Режим доступа: https://www.hse.ru/ news/communication/119812549.html (дата обращения 30.12.2020).

2. Борев Ю.Б. Комическое, или о том, как смех казнит несовершенство мира, очищает и обновляет человека и утверждает радость бытия. М.: Искусство, 1970.

3. Виноградов В.В. О теории художественной речи. М.: Высш.шк., 1971.

4. Attardo S. Translation and Humour // The Translator. 2002. Vol. 8. no 2. P. 173-194. Doi:10.1080/13556509.2002.10799131.

5. Цикушева И.В. Лингвистические средства создания комического эффекта в сказках // Вестник Адыгейского государственного университета. Серия 2: Филология и искусствоведение. 2008. Вып. 10. С. 100-103.

6. Лук А.Н. О чувстве юмора и остроумии. М.: Искусство, 1968.

7. Кязимов Г. Теория комического (проблемы языковых средств и приемов). Баку: Тахсил, 2004.

8. Брюханова E.A. Когнитивно-историческая природа иронии: парадигма моделей в сопоставительном описании: на материале английских художественных произведений XX века и их русских переводов [Электронный ресурс]: Дис...канд. филол. наук. Екатеринбург: РГБ, 2007.

9. Бахтин М. М. Сатира // Собрание сочинений: в 7 т. М.: Русские словари, 1997. Т. 5. C. $11-38$.

10. Горбачева И. М., Гришанова E. В. Роль смеховой коммуникации в социо-культурном развитии общества в кризисные периоды // Экономические и социально-гуманитарные исследования. 2018. № 2 (18). Режим доступа: http://esgi-miet.ru/images/Stati20182/esgi218-2018.pdf (дата обращения: 02.11.2019).

11. Грубова А. М. Стилистические приемы создания юмористического эффекта (на материале романа Хелен Филдинг «Дневник Бриджит Джонс») // Молодой ученый. 2017. № 11(145). С. 319-322.

12. Матасов Р.А. История кино/видео перевода // Вестник Московского университета. Сер. 22. Теория перевода. 2008. № 3. С. 3-27.

13. Матасов Р.А. Перевод кино/видео материалов: лингвокультурологические и дидактические аспекты: автореф. дис. канд. филол. наук. М.: Московский государственный университет имени М.В. Ломоносова, 2010.

14. Сазонов А. Дубль два (рус.) // Формула Кино Городовой. 2010. № 8. С. 51-53.

15. Снеткова М.С. К проблеме перевода художественных фильмов (на материале двух русских переводов фильма П. Альмодовара 'Женщины на грани нервного срыва') // Вестник Московского университета. Сер. 9. Филология. М., 2008. № 1. С. 56-62.

16. Татаринцев Н. С. Жанры в кинематографе // Молодой ученый. 2019. № 21 (259). C. $541-547$.

17. Федорова И.К. Перевод кинотекста в свете концепции культурного переноса: проблема переводческой адаптации // Вестник Челябинского государственного университета. Серия: Филология. Искусствоведение. 2009. № 43. С. 142-149.

18. Geopolitics. Volume 21, 2016 - Issue 1: article: Joe Thorogood Satire and Geoppolitics: Vulgarity, Ambiguity and the Body Grotesque University College London UK p. 215-235; 2016 Режим доступа: https://www.tandfonline.com/doi/full/10.1080/14650045.2015.1089433 (дата обращения: 02.01.2021).

19. Caricature and political cartoons: essential satire or old news [site]. Режим доступа: $\mathrm{https://www.itsnicethat.com/features/spitting-image-the-future-of-caricature-sculpture-illustration-}$ 071020 (дата обращения: 02.01.2021).

20. Словарь литературных терминов: [site]. Режим доступа: https://iteraryterms.net/satire (дата обращения: 02.01.2021).

21. South Park: [site]. Режим доступа: https://www.southparkstudios.com (дата обращения: 10.12.2020). 
22. Rick and Morty: [site]. Режим доступа: https://www.adultswim.com/videos/rick-and-morty (дата обращения: 17.12.2020).

23. Urban Dictionary: [site]. Режим доступа: https://www.urbandictionary.com/define.php?term= Totes\%20Malotes (дата обращения: 17.01.2021).

24. Family Guy: [site]. Режим доступа: https://www.fox.com/family-guy (дата обращения: 25.12.2020).

25. Longman Dictionary: [site]. Режим доступа: https://www.ldoceonline.com/dictionary/bribe (дата обращения: 02.01.2021)

26. F for Family: [site]. Режим доступа: https://www.netflix.com/f-for-family/ (дата обращения: 28.12.2020)

27. Statista: [site]. Режим доступа: https://www.statista.com/statistics/971473/number-k-12school-shootings-us (дата обращения: 02.01.2021).

\section{Information about the author:}

Olga V. Demina, PhD in Philology, Associate Professor of the Department of Theory and Practice of Foreign Languages RUDN Institute of Foreign Languages; research interests: lexicology, sociolinguistics, theory and practice of teaching foreign languages; e-mail: deptphilology@gmail.com

\section{Сведения об авторе:}

Демина Ольга Вадимовна, кандидат филологических наук, старший преподаватель кафедры теории и практики иностранных языков ИИЯ РУДН; научныле интересы: лексикология, социолингвистика, методика преподавания иностранных языков; e-mail: deptphilology@gmail.com 